\title{
Profesorowie Uniwersytetu Rolniczego i ich twórczość pozazawodowa
}

Spiritus flat ubi vult ${ }^{1}$.

Innym jeszcze razem kapryśne muzy upatrza sobie szacownego naukowca, czlowieka o umyśle konkretnym i ścistym, owszem, autora prac naukowych².

\section{ABSTRACT}

Professors of the University of Agriculture in Kraków and their non-professional work

The University of Agriculture is a technical school. Our Professors have unquestionable successes in the fields of sciences they specialise in. What is worth mentioning, is that some of them also show great talents in the area of humanities as authors of literary works, both poetry and prose. This paper discusses the profiles of three deceased 'technical humanities scientists': Professor Stefan Myczkowski, PhD., Professor Leszek Czuchajowski, PhD. Eng., and Professor Jan Koteja, PhD. Eng. All three professors represented the World War II generation: "the dark night of occupation"3 was the time of Myczkowski and Czuchajowski's youth and Koteja's young adolescence. Some of them did not live through the end of the Polish People's Republic to see the political transformation.

${ }^{1}$ Sentencja łac., „duch, kędy chce, tchnie”, tj. objawia się tam, gdzie chce; natchnienie od woli nie zależy, nie widomo skąd i jak przychodzi [w:] W. Kopaliński, Słownik wyrazów obcych i zwrotów obcojęzycznych z almanachem, Warszawa 1994.

2 M. Pilot, Wstęp [w:] L. Czuchajowski, Świat wedtug Józefa Dzioby, Warszawa 2009, s. 5.

${ }^{3}$ Cytat z napisu na krakowskim pomniku kardynała Stefana Adama Sapiehy: Modlitwa w ciemna noc okupacji. 
Keywords: the University of Agriculture in Kraków, the Professors of the University of Agriculture

Słowa kluczowe: Uniwersytet Rolniczy w Krakowie, profesorowie Uniwersytetu Rolniczego

Przez nazwę Uniwersytet Rolniczy im. Hugona Kołłątaja w Krakowie (2008) rozumie się wszystkie instytucje poprzedzające, a więc Akademię Rolniczą (1972), Wyższą Szkołę Rolniczą (1953), Wydział Leśny UJ (1949), Wydział Rolniczy UJ (1923), a wcześniej Studium Rolnicze przy Wydziale Filozoficznym Uniwersytetu Jagiellońskiego (1890). Można jeszcze przywołać historycznego asa - Katedrę Rolnictwa przy Akademii Krakowskiej (1806 - 1809)4 - efekt projektów KEN i reformy kołłątajowskiej.

Muzeum Uniwersytetu Rolniczego powołane zostało w roku 1976, za kadencji Rektora prof. dr. hab. Tadeusza Wojtaszka. Inicjatywę powstania Muzeum należy przypisać Dyrektorom Biblioteki Głównej - dr. Zdzisławowi Kosiekowi i dr Bożenie Pietrzyk, która po historycznych zawirowaniach, sukcesach i klęskach instytucji, powołała ją pow tórnie w roku 2014.

Muzeum UR działa w strukturze Biblioteki Głównej UR. Organizuje wystawy czasowe, bada przeszłość uczelni na tle zagadnienia nauki rolnictwa w Galicji. Początki nauczania rolnictwa w Polsce (bez państwa) to wiek XIX, więc historia tego tematu toczy się trzema nurtami - rosyjskim, pruskim i austriackim. Zagadnienia się jednak przeplatają i mają wspólne wątki, jak korzenie UR i SGGW sięgające Dublan, czyli Akademii Rolniczej założonej przez hrabiego Leona Ludwika Sapiehę w roku 1865, skąd wywodzą się np. profesorowie Emil Godlewski i Józef Mikułowski-Pomorski, filary intelektualne i organizacyjne (!) późniejszych szkół - krakowskiej i warszawskiej, które jako jedyne dziś w Polsce zachowały tradycyjną nazwę i nie przemianowały się na uczelnie przyrodnicze.

Niniejsze opracowanie nie ma na celu przedstawienia sylwetek zawodowych wymienionych profesorów. Ich działalność naukową dokładnie opisano w jubileuszowych wydawnictwach Uniwersytetu Rolniczego ${ }^{5}$. Wszyscy byli znanymi uczonymi z ważnymi osiągnięciami w swoich dziedzinach, doceniani w kraju i za granicą, nagradzani. Wyróżniali się szerokimi horyzontami, angażowali się w prawy społeczne, mieli rodziny, zainteresowania. Choć wydaje się, że praca naukowa była ich głównym zajęciem, żyli pełnią życia, wydawali się spełnieni w różnych obszarach działalności, jawią się jako szczęśliwi ludzie, mimo że ich losy układają się w sinusoidę radości i smutków. Każdy z nich mógłby się podpisać pod zdaniem: „Człowiekiem jestem i nic, co ludzkie, nie jest mi obce". Sukces wypracowali sami - pracą i talentem. Pamięć o nich na Uniwersytecie Rolniczym jest żywa.

${ }^{4}$ Katedra Rolnictwa zakończyła swoją działalność w wyniku zmian organizacyjnych spowodowanych wcieleniem Krakowa do Księstwa Warszawskiego we wrześniu 1809 roku i repolonizacją uczelni, w praktyce - kadra naukowa wróciła do Wiednia.

${ }^{5}$ Biografie profesorów pochodzą z książki Profesorowie, docenci i doktorzy habilitowani Wyższej Szkoty Rolniczej, Akademii Rolniczej, Uniwersytetu Rolniczego im. Hugona Koltątaja w Krakowie 1953-2013, t. 1, 2, red. J. Bieniek, E. Korostyńska, I. Pisiewicz, Kraków 2013.

${ }^{6}$ Słynna maksyma Terencjusza, rzymskiego myśliciela: Homo sum humani nihil a me alienum puto. 
Tytuły przywołanych w tym artykule książek układają się od ogółu do szczegółu od przyrody, ogólnego, przekrojowego tematu, opisanego z rozmachem, również objętościowym, poprzez opowieść o świecie z perspektywy pojedynczego człowieka (ja i reszta świata), do opisu świata wewnętrznego, zawężonego do przeżyć jednostki (mój świat wewnętrzny, tylko mój).

Być może istnieje zależność między wykształceniem a duchowością. Obcowanie z przyrodą, lasem, ziemią daje prawdopodobnie szerszą perspektywę oglądu świata i człowieka jako jego części, a także jako podmiotu, jednostki; kieruje myśl w głąb siebie - w to, co jawi się jako prywatne, metafizyczne, artystyczne.

Życie w bliskości mojego Ojca byto nieustająca przygodą. (...) na stryszku kaszubskiego domu napisat książę „Człowiek, przyroda, cywilizacja” uznana za książkę roku 1976.

Zbigniew Myczkowski ${ }^{7}$

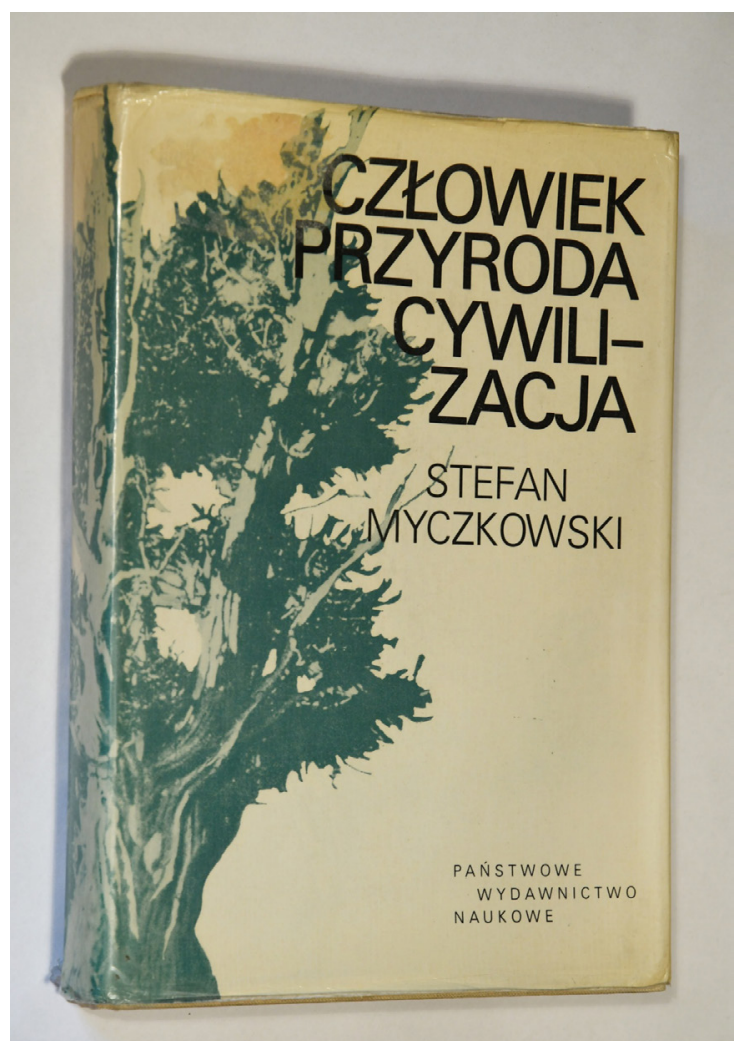

Il. 1. Stefan Myczkowski, Człowiek, przyroda, cywilizacja. Fot. G. Wojcieszek

${ }^{7}$ Z. Myczkowski, Wspomnienie o Ojcu, „Biuletyn okolicznościowy wydany przez Gimnazjum im. Profesora Stefana Myczkowskiego w Czarnej z okazji 10-lecia nadania imienia i sztandaru", s. 5. 
Profesor Stefan Myczkowski (1923-1977) - leśnik i niestrudzony działacz przyrody (z akcentem na słowo „niestrudzony”), urodził się w Jankowcach pod Jarosławiem. Do gimnazjum uczęszczał we Lwowie. W czasie okupacji pracował jako praktykant w nadleśnictwie Kańczuga. Był żołnierzem AK, a w wyniku aresztowania w 1944 roku stał się więźniem KL Flossenburg8. Po maturze w Jarosławiu i studiach na Wydziale Rolniczo-Leśnym UJ zdobywał kolejne stopnie naukowe. Pracował w wielu instytucjach, uczelniach krakowskich (PK, UJ, AGH, WSR), ale i w Zakopanem (Zakład Ochrony Przyrody PAN), Warszawie (SGGW), Gliwicach (Politechnika). Był prekursorem, a w latach 70. XX wieku pierwszoplanową postacią ruchu ochrony przyrody w Polsce. Za swoich mistrzów uznawał profesorów Władysława Szafera i Walerego Goetla. Angażował się w wiele działań społecznych komitetów, lig, ośrodków, komisji, rad, redakcji, związków, uczył, prowadził badania naukowe, pisał skrypty. Napisał także książkę popularną, z zacięciem literackim - lekturę dla każdego. Piękną recenzję wystawiła jej Zofia Radwańska-Paryska9:

Praca naukowa, którą czyta się jednym tchem, jak najciekawszą powieść, napisana z pasją twórczą, z rozmachem, z wyjątkową erudycją. Kopalnia wiadomości o ochronie przyrody i środowiska na całym świecie. Ilustrowana mnóstwem fotografii wykonanych przez autora wraz z synem. Książka, której nie powinno zabraknąć w żadnej bibliotece ${ }^{10}$.

To prawda, książkę czyta się jak powieść. Fragmentami jak powieść grozy...

Ze wspomnienia pośmiertnego o profesorze, pióra Zofii Radwańskiej-Paryskiej, dowiadujemy się również o wrażliwości uczonego, jego entuzjastycznym zapale do pracy, miłości do Tatr. Autorka przytacza wpis profesora do Księgi Gości Tatrzańskiej Stacji Naukowej, skreślony zapewne ad hoc, bez przygotowania, dlatego pokazujący ludzką twarz, emocje naukowca, dla którego praca zawodowa był integralną częścią życia:

Nie jest łatwo pisać o sprawach bliskich sercu, a takimi są i będą dla mnie wszystkie sprawy tatrzańskie. Tu, z tej Placówki Naukowej i pod przewodnictwem Państwa Paryskich, odbyła się pierwsza moja wyprawa w Tatry. To było i jest niezapomniane przeżycie. I potem tyle, tyle innych wypraw, narad, dyskusji, gdzie Tatry zawsze były, i albo „przyglądały się” nam bezpośrednio, albo z daleka, ale „były” i „mówiły”. A teraz też są i mówią do mnie najsilniej swoimi lasami. Uważam, że życie bez Tatr byłoby tylko połowiczne ${ }^{11}$.

Naczelnym hasłem książki Człowiek, przyroda, cywilizacja, jak podano we wstępie, jest ochrona przyrody dla człowieka, ale też - przed człowiekiem (il. 1). Autor zadziwia znajomością tematu i różnorodnością zainteresowań. Książka jest monografią, kompendium ówczesnego stanu wiedzy ekologicznej w Polsce. Myczkowski przytacza przepisy prawa,

${ }^{8}$ Zofia Paryska podaje również KL Langefeld w Saksonii [w:] Z. Radwańska-Paryska, Stefan Myczkowski: wspomnienie; ZRP. Materiały do wydanych, maszynopisy i rękopisy prac, artykułów i notatek drukowanych 1971-1990 [11], s. 5, Digital Library of Malopolska.

9 Zofia Radwańska-Paryska (1901-2001), botaniczka, taterniczka, pisarka, pierwsza kobieta-przewodnik tatrzański.

${ }^{10}$ Z. Radwańska-Paryska, op. cit., s. 6.

${ }^{11}$ Ibidem, s. 2. 
krajowe i światowe dane, nazwiska, liczby, cytuje badaczy, lekarzy, artystów. Z lekkością porusza się po różnych dziedzinach wiedzy - historii, geografii, polityce gospodarczej, literaturze, prawie. Ziemię traktuje całościowo: rośliny, zwierzęta, biosfera, środowisko, krajobraz, litosfera, zasoby przyrody, edukacja, ochrona przyrody i człowieka - wszystko to podlegało jego zainteresowaniu. Autor onieśmiela wiedzą ogólną, oczytaniem i kulturą słowa. Prowadzi opowieść rzetelnie i ciekawie, z wnikliwością naukowca i z obyczajową swadą. „Co godzinę kominy wypluwają do atmosfery $2400 \mathrm{~m}^{3}$ gazów i dymów”"12 - przytacza za dziennikarzem. Zaraz potem cytuje Sumienie Narodu i wyjaśnia:

Stefan Żeromski w Ludziach bezdomnych pisał o swoich wrażeniach z Paryża (...). „Widzę kamienną pustynię Paryża, pustą i brudną. Widzę także batogi popędzające tę pustynię wszerz”. (...) Tymi „batogami” były dla pisarza kominy fabryczne z pióropuszami dymu. Wizja Żeromskiego okazała się prawdziwa, jednakże Paryż obronił się przed dymami i to skutecznie ${ }^{13}$.

Lata 70. pod względem zanieczyszczenia powietrza były bardzo złym okresem dla Krakowa. Myszkowski pragnął nagłośnić problem, rozpowszechnić wiedzę o nim. Zależało mu na szerokim odbiorze. Popularyzował temat - jak sam przyznawał - kosztem świadomego uproszczenia zagadnienia. Książka miała być i jest dla każdego. Zamierzony efekt został osiągnięty przeplataniem rzeczywistości fikcją, teraźniejszości - historią, spraw ogólnych - szczegółami, a opisy Polski - opisami odległych rejonów świata. Profesor, jak nikt inny, zdawał sobie sprawę z kondycji środowiska naturalnego połowy XX wieku, mimo to nie tracił wiary w potęgę człowieka, która: „Jeśli mogła być aż tak niszcząca, gwarantuje pewność naprawy"14. Czy omawianą książkę można zaliczyć do literatury pięknej? Na pewno wyróżnia się sprawnym językiem, sporadycznymi figurami stylistycznymi czy choćby wyszukanymi określeniami, np. „nielotny człowiek”: „Niejeden ptak - nielot znalazł się na liście straconych dla naszego świata gatunków, ponieważ możność ich ucieczki przed także nielotnym człowiekiem była znikoma"15. Zawiera cytowania klasyki, przywołuje historię: „Podobnie i rozległa Puszcza Notecka, była doskonałą zaporą obronną przed groźnymi dla Polan Obodrytami czy Lutykami i długo przetrwała na rubieżach ówczesnych polskich ziem"'16. Propaguje idee humanistyczne, nawiązuje do kultury:

Przyroda w twórczości wszelkiego rodzaju to nie tylko temat. Była ona i jest nieodłączną częścią twórczości, (...) wszystko, co ludzkie, dzieje się w przyrodzie, jako powszechnej i niezastąpionej arenie działania. Przyroda była dla twórców nie tylko tłem, lecz i treścią przeżyć artystycznych ${ }^{17}$.

Jeżeli nawet książka nie całkiem mieści się w definicji literatury pięknej, to jest to piękna literatura. Piękna książka napisana z polotem i talentem.

12 S. Myczkowski, Człowiek, przyroda, cywilizacja. Ksztaltowanie zasobów przyrody oraz ochrona biosfery, Kraków 1976, s. 233.

${ }^{13}$ Ibidem, s. 234.

${ }^{14}$ Ibidem, s. 7 (jest to parafraza zdania prof. W. Goetla: „Co technika i przemysł zepsuły, to technicy powinni naprawić").

15 Ibidem, s. 61.

16 Ibidem, s. 14.

${ }^{17}$ Ibidem, s. 111. 
Stefan Myczkowski jest laureatem nagrody imienia Włodzimierza Pietrzaka ${ }^{18}$ nomen omen $\mathrm{w}$ dziedzinie literatury ${ }^{19}$.

Profesor był specjalistą w dziedzinie fitosocjologii zbiorowisk leśnych, uwieńczeniem jego badań był skrypt Zarys fitosocjologii leśnej Polski oraz opracowania z tej dziedziny dotyczące drzewostanu Tatr. Działał w komitetach PAN. W uznaniu zasług tego uczonego imię Stefana Myczkowskiego noszą Podyplomowe Studium Ochrony Przyrody UR, sala wykładowa na Wydziale Leśnym UR, ulice w trzech miastach, rezerwat przyrody i kilka szkół.

Spiritus flat ubi vult.

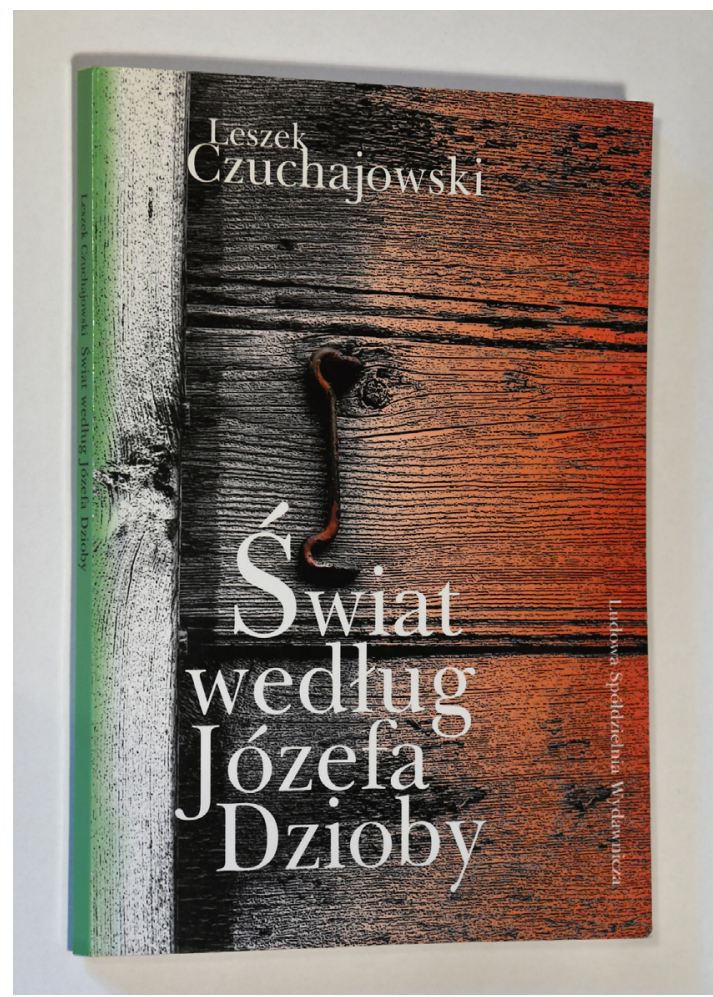

Il. 2. Leszek Czuchajowski, Świat wedtug Józefa Dzioby. Fot. G. Wojcieszek

Leszek Czuchajowski debiutował literacko w wieku 62 lat. Poczynając od roku 1988, napisał i wydał 25 zbiorów poezji w języku polskim i 6 po angielsku. Należał do krakowskiego oddziału Stowarzyszenia Pisarzy Polskich i International Society of Poets, przez które został nominowany Poetą Roku 2000.

${ }^{18}$ Wyróżnienie niepaństwowe, przyznawane od roku 1948 za wybitną twórczość, będącą świadectwem uniwersalnych wartości i postaw ludzkich, chrześcijańskich i patriotycznych.

${ }^{19}$ Informacja zamieszczona [w:] Z. Radwańska-Paryska, op. cit., s. 6. 
Profesor Leszek Czuchajowski (1926-2016) był chemikiem. Urodzony we Lwowie w dzieciństwie przeniósł się z rodzicami do Krakowa. Jego ojciec był doktorem prawa, absolwentem trzech uczelni, kapitanem rezerwy, komisarycznym prezydentem Krakowa, ostatnim przed wojną ${ }^{20}$. Młodość Profesora to tajne komplety, Szare Szeregi i AK. Jako syn przedwojennego decydenta nie miał łatwo w powojennej rzeczywistości. Ukończył Politechnikę Śląską, doktorat i habilitację obronił na AGH, gdzie pracował u progu kariery. Po stypendium zagranicznym w latach 60. objął Katedrę Chemii Ogólnej Wyższej Szkoły Rolniczej, którą kierował dziewięć lat. Ostatnie miejsce pracy w Polsce to Uniwersytet Śląski w Katowicach, gdzie był prorektorem i członkiem Solidarności, stąd w 1981 roku wyemigrował i osiadł wraz z rodziną w USA. Tam pracował jako profesor chemii na trzech uniwersytetach - Southern Illinois, Kansas State i University of Idaho, prowadząc jednocześnie badania naukowe. Był członkiem zagranicznym PAU. Pod koniec życia wrócił do Krakowa. Profesor Czuchajowski był chemikiem i poetą. Jedną książkę napisał prozą - wydany przez LSW w roku 2009 Świat wedtug Józefa Dzioby (il. 2). Jest to zbiór 98 opowiadań, choć formą przypominają wiersz. Autor spisał i opracował opowieści swojego teścia, ojca pierwszej żony Zuzanny, i im książkę zadedykował. Zastosowanie formy wiersza wymusiło iście chemiczną syntezę i precyzję. Nie doszukamy się w książce zbędnych słów. Natomiast skrót formy robi wrażenie na czytelniku. Tekst jest konkretny, jak konkretny był narrator - twardy chłop z Gruszowa (okolice Nowego Brzeska), odpowiedzialny, zasadniczy i pogodzony z niewyobrażalnie, według dzisiejszych kryteriów, trudnym życiem. Lektura pozostawia przestrzeń do samodzielnej interpretacji i to jest jej olbrzymia wartość. Autor nie tłumaczy, nie poucza, nie wartościuje, nie bagatelizuje ani nie wyolbrzymia. Jakby mówił - takie jest życie, tacy są ludzie i, jak batem, smaga słowem prostym, a dobitnym. Przypowieści są krótkie, jednak zostają z czytelnikiem na długo.

Wspomnienia zawierają obrazki, eufemistycznie mówiąc, wesołe i smutne. Oto fragmenty dwóch anegdot, dla orientacji w charakterze książki:

\author{
Dwór \\ Przed wojną dwór to był \\ gorszy niż kołchoz, \\ ja już wiem, co mówię; \\ moja mama mi opowiadała, \\ że jej pradziadka dziedzic \\ siekierą zarąbał na łóżku \\ że chorował i w żniwa \\ nie poszedł do roboty, \\ tyle prawda, że to było \\ sto pięćdziesiąt lat temu $(\ldots)^{21}$.
}

${ }^{20}$ Bolesław Czuchajowski był prezydentem Krakowa od 21 kwietnia do 2 września 1939 roku. Został rozstrzelany w KL Auschwitz 3 sierpnia 1941 roku.

${ }^{21}$ L. Czuchajowski, op. cit., s. 9. 


\section{Zegarek szwajcarski}

Pamiętasz Zuziu, jakem zażartował,

że jak będziesz miała same piątki

od góry do dołu, to ci kupię

zegarek szwajcarski i pięć sukienek?

no i zajeżdżam do Tarnowa

a ona hyc mi na szyję i mówi,

że od góry same piątki,

a ja przywiozłem w nocy

kilka ton węgla, żeby mieć

pieniądze, żeby nie było tak,

żem se żartował, no i poszliśmy,

kupiłem wtedy ten zegarek,

pamiętam za 2300 złotych,

to wtedy tyle krowa kosztowała,

no $i$ te sukienki, taką czerwoną

w czarne oczka, jakem obiecał,

to nigdy w życiu nie zawiodłem

no i teraz też nie ${ }^{22}$.

\section{Ze wstępu Mariana Pilota:}

Wszystko bowiem, co życie niesie, jest między pierwszą a dziewięćdziesiątą opowieścią słowiarza: miłość, nienawiść, zdrada, wojna, służba wojskowa, bolszewicy, hitlerowcy, Żydzi, Ukraińcy, Amerykanie, wieś Gruszów i cały świat, widziany oczyma chłopskiego mędrca i jego słowami powiedziany, ołówkiem i piórem poety z wielkim staraniem i czułością zapisany. Niepowtarzalne, samoswoje dzieło. Ostatnia chłopska epopeja ${ }^{23}$.

Dla Czuchajowskiego, jedynaka z profesorskiej rodziny, inteligenta od pokoleń, zderzenie z chłopską mentalnością musiało być ciekawym i mocnym przeżyciem do tego stopnia, że uwiecznił to zapisem, zachował tę filozofię dla nas, dla przyszłych pokoleń. Czytającemu podczas lektury towarzyszą najczęściej dwie myśli: tego świata już nie ma. I druga: czy tego świata na pewno już nie ma? Chłopska epopeja to w świadomości Polaka powieść Chłopi, owszem istnieje tematyczne podobieństwo. Natomiast lapidarna forma przywodzi na myśl opowiadania Tadeusza Borowskiego, Zofii Nałkowskiej, Hanny Krall - zło, spotęgowane przez okoliczności, nie wymaga dodatkowej interpretacji.

I jeszcze fragment wspomnień Profesora, pokazujący jego ciepły i żartobliwy stosunek do własnej twórczości:

Dziś w nocy przyśnił mi się mój nauczyciel polskiego. Machając dziennikiem, krzyknął mi do ucha: „Zawsze byłeś u mnie kiepski, ale teraz to co innego, w poezji wszystko dozwo-

\footnotetext{
${ }^{22}$ Ibidem, s. 92.

${ }^{23}$ M. Pilot, Wstęp [w:] L. Czuchajowski, op. cit., s. 8.
} 
lone, bez kropek, przecinków, nie wiadomo, o co chodzi, nie przejmuj się, nie szkodzi, pisz dalej" ${ }^{24}$.

Profesor był autorem lub współautorem 120 oryginalnych publikacji naukowych z zakresu chemii organicznej, z których cenił szczególnie prace o syntezach aminokwasów w wyładowaniach elektrycznych w gazach, zsyntetyzowaniu nowych heterocyklofanów, a także porfiryn z dołączonymi cyklofanami i nukleozydami.

Że Ojciec przeszedt chorobę Heinego-Medina, wiedziatem od dzieciństwa (...), ale zarazem nie przychodziło mi do głowy, że byt niepetnosprawny. Tym mniej przypuszczałem, że on sam mógt postrzegać siebie jako niepelnosprawnego, że problem niepetnosprawności mógł go kiedykolwiek nurtować. A już zwłaszcza w pamiętnym roku '81. Paweł Koteja ${ }^{25}$

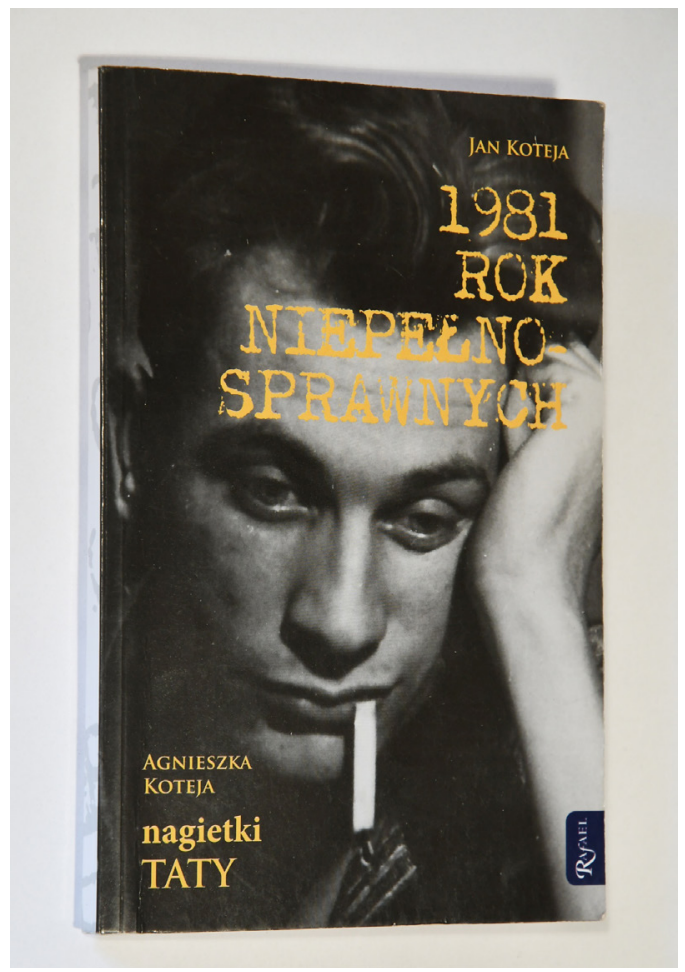

II. 3. Jan Koteja, 1981. Rok Niepelnosprawnych. Fot. G. Wojcieszek

${ }^{24}$ Z biogramu L. Czuchajowskiego na stronie Stowarzyszenia Pisarzy Polskich Oddział w Krakowie, http://www.sppkrakow.pl/czlonkowie/leszek-czuchajowski/ [dostęp: 3.12.2017].

${ }_{25}$ P. Koteja, Inkluzje albo wprowadzenie do Roku Niepetnosprawnych i Nagietek Taty [w:] J. Koteja, 1981. Rok Niepetnosprawnych, A. Koteja, Nagietki Taty, Kraków 2008, s. 11. 
Profesor Jan Koteja (1932-2004) był zoologiem, entomologiem, paleontologiem. Urodził się w Siemianowicach Śląskich. Studiował na Wydziale Biologii i Nauk o Ziemi UJ, był profesorem doktorem habilitowanym nauk przyrodniczych w zakresie zoologii. Związany był z Uniwersytetem Rolniczym od pierwszej pracy do emerytury w ciągu całego zawodowego życia. Kierownik Katedry Zoologii, prorektor, członek Senatu i komisji senackich, rad i instytutów PAN, Muzeum Ziemi PAN w Warszawie, polskich, europejskich i światowych organizacji dotyczących nauki, zwłaszcza problemu skamieniałości, był redaktorem naczelnym „Polskiego Pisma Entomologicznego”, redaktorem międzynarodowego biuletynu „Meganeura” oraz redaktorem i wydawcą biuletynu „Inclusion - Wrostek". Pełnił funkcję przewodniczącego komisji Uczelnianej NSZZ Solidarność AR, redagował i wydawał akademickie pismo „Sowizdrzał - Listy Bractwa Sowizdrzalskiego w Krakowie", związany był również ze środowiskiem miesięcznika „Forum Akademickie”.

Profesor lubił i umiał pisać. Miał lekkie pióro. Impulsem (w języku biologa pewnie katalizatorem) do przelania na papier nagromadzonych przez dziesięciolecia emocji i refleksji, były plakat i hasło: „1981 Międzynarodowy Rok Ludzi Niepełnosprawnych”: „Z (...) uczuć i myśli, które mi się snuły po głowie, a przede wszystkim z obrazów, nieraz odległych w czasie, które ten plakat wywołał, zrodziły się te opowiadania"26. Zapiski powstały między lipcem a grudniem, znamienna jest data wstępu czy podsumowania ostatni dzień roku. Profesor pisał dla siebie, z wewnętrznej potrzeby, systematyzował i układał ważne dla niego momenty w życiu:

To było pisane nocą. (...) W nocy wszystko jest możliwe. (...) Co ostałoby się z tych opowiadań, gdyby je oświetlić ostrym światłem słońca? (...) może zmieniły by się w garść popiołu (...)? Obawiam się, że tak by się stało. Niech więc pozostaną w ciszy i mroku nocy... I stanu wojennego, $\mathrm{z}$ redakcjami zamkniętymi siedmioma pieczęciami ${ }^{27}$.

Książka 1981 Rok Niepetnosprawnych, wydana pośmiertnie przez dzieci profesora, Dom Wydawniczy Rafael w 2008 roku (il. 3), ma trzy warstwy. Pierwsza to trwające wspomnienia niemiłych sytuacji, o nich się na co dzień nie pamięta, ale właśnie one zalegają. Można się z nimi zmierzyć na chłodno po upływie czasu jeszcze raz. To rodzaj terapii, autoterapii. Refrenem tej części planu mogłyby być słowa: „,o cię nie zabije, to cię wzmocni". Druga warstwa, zawierająca wszystkie chyba odcienie i smaki ironii, również, a właściwie przede wszystkim - gorzki na temat: niepełnosprawny, czyli kto? Profesor, z inteligentną i wysublimowaną ironią - autoironią, ciętą i trafioną - próbuje zredefiniować pojemne pojęcie niepełnosprawności:

Dla lekarzy, społeczników, moralistów, psychologów niepełnosprawny i inwalida są przypadkami - ciężkimi, zwyczajnymi, wyjątkowymi lub interesującymi. Niepełnosprawność i inwalidztwo to zagadnienia, problemy, zjawiska..., też ciekawe, trudne, złożone itp. (...) W ciągu ewolucyjnym eufemizmów od pokraki i kaleki przez ułomnego, inwalidę, niepełnosprawnego, na końcu albo na szczycie znajduje się „słaby”. I tu wpadamy w zupełną rozterkę. O jaką siłę i słabość chodzi?

\footnotetext{
${ }^{26}$ J. Koteja, op. cit., s. 15.

${ }^{27}$ Ibidem, s. 16.
} 
Którędy ma przebiegać linia podziału? Czy wśród niepełnosprawnych, tych z legitymacjami i bez, nie ma przynajmniej tylu mocarzy, ilu wśród pełnosprawnych?28

Trzecia warstwa książki to podsumowanie i wnioski dotyczące tego, jak traktować, jak pomagać ,sprawnym inaczej”:

Wszelkie działania na rzecz ludzi, którym poświęcony jest Międzynarodowy Rok 1981, powinny być podporządkowane zasadzie, lub założeniu, że „nieświadomość kształtuje byt”. Innymi słowy: wszystko to dobrze służy człowiekowi niepełnosprawnemu (a każdy z nas jest w jakiejś dziedzinie mało sprawny), jego szczęśliwemu bytowaniu na tym świecie, co prowadzi do nieświadomości, albo braku poczucia własnej niepełnosprawności. Tworzenie Spółdzielni Inwalidów, Związku Niewidomych, proklamowania Dnia czy Roku Niepełnosprawnych nie prowadzi do celu, który instytucje czy imprezy te zakładają. Mocny związek inwalidów „broniący interesów swoich członków" eksponuje niepełnosprawność tych ludzi, pogłębia podział społeczny. Tymczasem (...) chodzi o to, by niesprawni byli szczęśliwi wśród sprawnych, a nie w swoim getcie. (...) w życiu jednak silniejsze są tendencje dezintegracyjne i separatystyczne. Znacznie łatwiej „przekonać” ludzi, że są lepsi, ważniejsi czy pokrzywdzeni, że powinni się wobec tego zamknąć we własnym kręgu i odizolować od innych. Chińskie mury są, i pewnie za zawsze pozostaną, najtrwalszymi budowlami na tej ziemi ${ }^{29}$.

Profesor był zwolennikiem integracji, ale też tolerancji, akceptacji, zacierania różnic, nieeksponowania inności, niewyrzucania poza społeczny nawias:

Oczywiście, organizacyjne formy troski o ludzi niepełnosprawnych i upośledzonych na pewno są potrzebne, ale... czy nie sądzicie, że jeden wariat wśród stu normalnych nie zarazi swoim wariactwem tych stu normalnych, sam natomiast może mieć jakieś szanse powrotu do normalności? A mało prawdopodobne jest, że w szpitalu wariatów wariaci wpływają na siebie kojąco i leczniczo? $?^{30}$

Profesor Koteja był prekursorem idei integracyjnych, które w Polsce od 30 lat są forsowane przez świadome kręgi zainteresowanych, z różną akceptacją niezainteresowanych, to prawda, „chińskie mury” to budowle trwałe. Każde ograniczenie rodzi dodatkową barierę, każdy „obdarowany” balastem ma dwa wyjścia - poddać się lub walczyć, jeśli walczyć, często zwyciężyć, przezwyciężyć, wygrać. Integracja - tak, getta dla niepełnosprawnych - nie, natomiast związki wspierające są ważną częścią ,,̇̇ycia z...”, także organizacje samopomocowe ludzi, których łączy wspólny problem, są uznanym dziś na świecie sposobem pomocy przez - potrzebną i skuteczną - samopomoc. Nie każdy z ograniczeniem ruchowym zastaje profesorem nauk przyrodniczych, nie każdy niewidomy światowej sławy tenorem i nie każdy uwięziony w ciele ma w zamian za to mózg Hawkinga. Jest jeszcze rzesza takich, którzy oprócz „,niełatwego daru” nie dostali od losu wiele więcej. Autor patrzy na problem z dwóch perspektyw, z obu biegunów, ale

\footnotetext{
${ }^{28}$ Ibidem, s. 56.

${ }^{29}$ Ibidem, s. 75.

${ }^{30}$ Ibidem, s. 52.
} 
i z wysokości swojego intelektu, samodzielności i siły. Profesor był niezwykle sprawnym niepełnosprawnym. Książka profesora Kotei jest wpisana w nurt samopomocy, co podkreśla we wstępie Janina Ochojska-Okońska, cytując lekarza Lecha Wierusza ${ }^{31}$ : „Wszyscy jesteśmy czymś obdarowani, nie zawsze jest to dar łatwy. (...) książka jest dla tych, którzy otrzymali niełatwy dar"32. A Leszek Aleksander Moczulski (zmarły w grudniu 2017 roku) w liście do Agnieszki Kotei przyznaje: „Z tekstem Państwa Taty to trochę tak jak z listem zamkniętym w butelce i wrzuconym do morza z wiarą, że list ten dotrze do ludzi, którym wiadomości listu są niezbędne do życia" ${ }^{33}$. O książce Jana Kotei dowiedziałam się od Anny Kapusty, która opisała ją w „Biuletynie Biura ds. Osób Niepełnosprawnych” w roku 2011, skupiając się na nowatorstwie tez autora, przystępności narracji, spotkaniu z samym sobą i zjawisku inkluzji, w rozumieniu integracji.

Profesor pracował nad czerwcami (owadami z grupy pluskwiaków), był autorem 700 prac naukowych i artykułów z dziedziny morfologii, anatomii, biologii, ekologii, faunistyki, systematyki, paleontologii i ochrony roślin oraz opracowań podręczników, wyróżniony nagrodą „Bursztynnik roku 2000” przez Międzynarodowe Stowarzyszenie Bursztynników za propagowanie bursztynu i promowanie badań nad inkluzjami bursztynowymi na arenie międzynarodowej.

Może należałoby podkreślić, że z omówionych lektur bije również optymizm, Józef Dzioba piórem profesora Czuchajowskiego opowiada też miłe historie, a wspomnienia profesora Kotei z okresu dzieciństwa, takie jak Patrz, z czego żyjesz - bawią do łez (radości!). Zadymiony Kraków - zmartwienie profesora Myczkowskiego - przynajmniej walczy ze smogiem, a okoliczne huty zostały unieszkodliwione.

Celem artykułu było przedstawienie trzech wybitnych osobowości związanych z Uniwersytetem Rolniczym. W ich życiu możemy znaleźć swoiste drogowskazy. Zachęcam do bliskich spotkań z Profesorami, oni nadal żyją w swoich książkach. Można ich też po prostu odwiedzić, spoczywają na cmentarzu Rakowickim w Krakowie. Znowu razem.

\section{Bibliografia}

Biogram Leszka Czuchajowskiego, Strona Stowarzyszenia Pisarzy Polskich Oddział w Krakowie, http://www.sppkrakow.pl/czlonkowie/leszek-czuchajowski/ [dostęp: 3.12.2017].

Czuchajowski L., Świat wedtug Józefa Dzioby, Warszawa 2009.

Kapusta A., 1981. Rok Niepetnosprawnych. O inkluzji wedlug Jana Kotei, „Biuletyn Biura ds. Osób Niepełnosprawnych Uniwersytetu Jagiellońskiego" 2011, nr 3, s. 20-30.

Kopaliński W., Stownik wyrazów obcych $i$ zwrotów obcojęzycznych z almanachem, Warszawa 1994.

Koteja J., 1981. Rok Niepetnosprawnych, Koteja A., Nagietki Taty, Kraków 2008.

Myczkowski S., Człowiek, przyroda, cywilizacja. Kształtowanie zasobów przyrody oraz biosfery, Warszawa 1976.

${ }^{31}$ Lech Wierusz (1917-1987) lekarz ortopeda, dyrektor Zakładu Leczniczo-Wychowawczego dla

Dzieci Kalekich w Świebodzinie.

${ }^{32}$ Motto dr. Wierusza, według Janiny Ochojskiej-Okońskiej: „Wy możecie więcej, a nie mniej.

Wam dano, a nie odebrano".

${ }_{33}$ Z listu Leszka Aleksandra Moczulskiego do s. Agnieszki Kotei [w:] J. Koteja, op. cit., s. 8. 
Myczkowski Z., Wspomnienie o Ojcu, „Biuletyn okolicznościowy wydany przez Gimnazjum im. Profesora Stefana Myczkowskiego w Czarnej z okazji 10-lecia nadania imienia i sztandaru", http://docplayer.pl/5204546-Biuletyn-okolicznosciowy-wydany-przez-gimnazjum-im-prof-stefana-myczkowskiego-w-czarnej-z-okazji-10-lecia-nadania-imienia-i-sztandaru.html [dostęp: 11.12.2017].

Profesorowie, docenci i doktorzy habilitowani Wyższej Szkoły Rolniczej, Akademii Rolniczej, Uniwersytetu Rolniczego im. Hugona Kotłataja w Krakowie 1953-2013, red. J. Bieniek, E. Korostyńska, I. Pisiewicz, t. 1 i 2, Kraków 2013.

Radwańska-Paryska Z., Stefan Myczkowski: wspomnienie; ZRP. Materiały do wydanych, maszynopisy i rękopisy prac, artykułów i notatek drukowanych 1971-1990 [11], Digital Library of Małopolska, http://mbc.malopolska.pl/dlibra/docmetadata?id=81400\&from=publication [dostęp: 13.12.2017]. 